\title{
Agency Cost and Management Behavior: The Role of Performance as a Moderator
}

\author{
Moayad Mohammad Ali Fadhl Alfadhl ${ }^{1}$, Tariq Tawfeeq Yousif Alabdullah ${ }^{2}$ \\ ${ }^{1}$ College of Administration and Economics, Accounting Department Al-Qadisiya University, Iraq \\ ${ }^{2}$ College of Administration and Economics, Accounting Department University of Basrah, Iraq
}

\begin{abstract}
The purpose of the current study is to examine the relation between management behavior determinants and agency cost. Moreover, the current study investigates the moderating impact of company performance on such relationship. To achieve the objective of this study, three determinants have been used for management behavior, namely: management ownership, financial leverage, and information asymmetry. The sample of the current study is 27 companies distributed to three sectors: service, bank, and industry sectors in Iraq. The results revealed that there is a significant relationship between management ownership and agency cost; and this relationship is affected by the moderating role of firm performance. The results also confirm there is no relationship between financial leverage and information asymmetry, and agency cost. Besides, there is no impact of company performance on such relationship.
\end{abstract}

Keywords: Agency cost, management ownership, financial leverage, information asymmetry, company performance, Iraq

\section{Introduction}

Agency Theory, as explained by Jensen and Meckling (1976), deals with two parties: the stockholders and management; the former works on behalf of the latter. It therefore investigates the behaviors and economies of the role of these parties based on some rules; the first is economic analysis within the firm; second lies in dealing with behavioral analysis of the groups which make up the firm; third is represented by accounting analysis to represent agency cost as a predictable result of conflict between stockholders and managers; and the last rule lies in the legal analysis that must be done between all these parties to solve problems (Chen and Fang, 2011).

Jensen and Meckling (1976) and alabdullah et al. (2014) show, within the structure of stockholders' and management's behaviors, that the task of management represented by being delegated by stockholders to run available firm resources and negotiate with other parties on their behalf, should therefore achieve positive outcomes in which those resources might be utilized and stockholders' wealth maximized. Jensen and Meckling explain that in the case of managers having a high percentage of a company stock, where this will lead to the probability of the conflict of interests to be disappeared. However, when the capital structure of the firm is fragmented over a number of stockholders, and the need to rely on outsiders, this might create concern of interests by stockholders, particularly when the managers do not have the right to have cash flows achieved from the outstanding performance of the firm's recourses only of the agreed extent.

Several previous studies in the literature (Jensen, 1998; Wu et al., 2011; Wang 2010) admitted that agency problems are related to the level of extent of conflict between management and stockholders' rights in cash flows, and further extending the researcher efforts in such a vital respect, the current study aims at present practical evidences derived from the context of Iraqi environment regarding to agency cost and the illustration of its relation with some of determinants of the management behavior for this cost, like management ownership, financial leverage, and then examining the moderating role of performance impact on the relation between these determinants and agency cost. Therefore, the problem of the present study is represented by the following questions: what are the agency costs rates of growth 2010 -2013? Is the agency cost affected by the determinants: managerial ownership, financial leverage, and information asymmetry? Is there an effect of the performance as a moderator on the relation between these variables and agency cost?

In this regard, the importance of the current study is divided by two sides: practical and theoretical. Theoretically, the current study deals with agency problems represented by agency costs as a proxy throughout agency theory. Furthermore, it deals with some important determinants of management behavior. In addition, the present study takes into consideration the firm performance impact. The importance of the practical side lies in dealing with agency problems in the Iraqi firms that may reduce agency costs and improve some polices related to performance effect. In that, this may participate in creating value of the firms listed in the financial market in Iraq, especially there is a declineinthe management performance of Iraqi firms that led to serious problems and financial corruption in the Iraqi context (Alabdullah et al, 2014).

\section{Literature Review}

\subsection{Agency Cost}

The ownership role is theoretically discussed by Jensen and Meckling (1976) who demonstrated that agency cost between management and stockholders could be pretty costly in case the interests of these two parties are not aligned and this will affect stockholders' benefit, and in such a way eventually impactthe company value. The result of agency problem leads to agency costs which are represented by the separation of ownership and control. They have defined agency cost as a monitoring expenditures' sum by the stockholders, bonding expenditures by the managers, and the residual costs.

\section{Volume 5 Issue 1, January 2016 www.ijsr.net}




\section{International Journal of Science and Research (IJSR) \\ ISSN (Online): 2319-7064}

Index Copernicus Value (2013): 6.14 | Impact Factor (2014): 5.611

\subsection{Management Behavior Determinants}

Towards appearance of agency cost it has been shown that the researchers declare that within the agency theory concept, the reasons for agency cost could be recognized to one or more of the managerial behaviors determinants:

- Management ownership: As mentioned by Alabdullah et al (2014) that since the time of the study by the economists Berle and Means (1932) which admits what has been demonstrated by Adam Smith over three centuries in his book titled "The Wealth of Nations", he warned of the possible problems of the corporate absent ownership because ofthe issue of separation between ownership and stewardship raised in the joint-stock companies, mentioning that managers are impossible to be expected to be as watchful as if they owned such money. Absent ownership has been deemed as one of the most vital agency cost sources. Previous studies (e.g, Fama and Jensen, 1983; Chuang et al., 2010) reveal evidence showing that increasing separation ownership and control lead to the inevitability of increased agency problems. They show that there is a strong relationship between the management ownership in cash flows and agency costs. They disclose that increasing management ownership in cash flow would lead to motivate managers of the company to work hard in order to maximize their personal wealth. Since managers' wealth is related to other stockholders' wealth in the firm, no conflict ofinterests will exist; thus, no agency costs.

- Information asymmetry: Jensen and Meckling (1976) used agency theory to address problems of control between managers and owners, which emerged due to information asymmetry.

It is another source of conflicts regarding agency problems. Top management provides information in the reports when readers expect that such information strongly reflects a good condition of work progress, while top management uses this information to get decisions and performance leading to get their own interests. In line with this idea, Harris and Raviv (2010) demonstrate that the information would not be fully revealed on the part of the top management because of agency problems.

- Financial leverage: From the perspective of agency theory, the optimal capital and ownership structure might be used to limit agency costs (Al-Najjar, 2010). Thus, it is expected that high capital structure in the company provides a negative indication that the company faces future financial problems, and thus investors prefer low leveraged companies (Tong and Ning, 2004).

Pinteris (2002) examines sample of banking sectors in Argentine. The objective is the existence of agency problems between stockholders and management from one hand, and the stakeholders and banking institutions, from the other. Moreover he provides evidences related to the impact of ownership concentration on both performance and agency cost using available data related to bank sector in the period 1997-1999. The findings reveal a negative relationship between performance and ownership concentration. Moreover, he finds that the banks that have a high ownership concentration must have higher risk on bank's loan portfolio; and therefore they have a high agency cost as compared to other banks that have lower ownership concentration. The findings of this study reveal a strong conflict between shareholders and banks' management due to the asymmetric information. Abor (2007) investigates the effect of capital structure on the firm performance of (SMEs) in Ghana and South Africa. This study used different measures of firm performance; the results indicate that capital structure has influences on firm performance, in general but not exclusively. Furthermore, the results show that capital structure, especially total debt ratios and long term, negatively affects firm performance of SMEs. This suggests that agency matters might lead to SMEs pursuing high debt policy, therefore resulting in lower firm performance. Al-Malkawi (2007) investigates the determinants of corporate dividend policy in the Jordanian context. This study utilized panel data set of all traded companies on the Amman Stock Exchange (ASE) in the period $1989-2000$. He develops eight hypotheses that are used to represent the essential theories of corporate dividends. . This study investigates the determinants of the dividends amount using Tobit specifications. The findings revealed that the proportion of stocks held by managers and state ownership has a significant affect on the amount of dividends paid. Age, size, and profitability of the company seem to be determinants of corporate dividend in Jordan. The results provide support for the agency costs hypothesis and consistent with the pecking order hypothesis.

\section{Methodology}

In the current study, the researcher has made the following basic hypotheses based on the questions of the study problem:

H1: Agency cost in a year is equal to / less than the agency cost for the firm in previous year.

$\mathrm{H} 2$ : Agency cost is not affected by the determinants: management ownership, financial leverage, and information asymmetry.

H3: There is no effect of firm performance on the relation between agency cost and all determinants of managerial behavior. Therefore, there is no effect of the three determinants in determining this relationship.

The current study consists of independent variables (percentage of management ownership, financial leverage, and information asymmetry), and dependent variable represented by agency cost, and a moderator variable, performance. The independent variables in the current study are listed below:

1. Management ownership: The model suggested by Jensen and Meckling (1976) show that an increase in the ratio of company's equity owned by managers is expected to increase company value as the interest of all shareholders are realigned, and therefore there is a reduced need for concentrated audit.

There are diversities about the modes of explaning this variable made by the previous studies. Some of the previous studies measured it by the common stocks held by 


\section{International Journal of Science and Research (IJSR) \\ ISSN (Online): 2319-7064}

Index Copernicus Value (2013): 6.14 | Impact Factor (2014): 5.611

the members of board of directors divided by total common stocks being outstanding; while others used the cumulative percentage to have more than $3 \%$ of the shares of percentage owned by managers in the firm (Chen et al., 2006). The present study will utilize the common stocks held by the members of board of directors divided by total common stocks outstanding because the opportunity of providing information in Iraqi firms fit with this measurement. To test the effect of such a variable on agency cost, the researcher perusesto investigate the effect of this variable on theownership agency; furthermore the researcherclassified the sample firms into two groups through using the mediator rate of management ownership, describing firms where the management ownership is higher than the value of the mediator, whilst describing firms where management ownership is already less than the mediator value as firms with a low rate. This case is shown in Table (1) that shows distribution of the sample of study according to the percentage of management ownership. It must be noted that the highest average percentage of management ownership appeared in the banking sector because of the family nature of firms that imposes ownership highly on the management, distinguishing them from other firms that rely on job experience of non owners in the management of its activities. There is a survey conducted by the researcher revealing that $63.6 \%$ of executives in the banking firms are shareholders.

2. Information asymmetry: It has been measured by the market value ratio of book value being the measurement of growth. When this ratio rises, there will be a high information asymmetry with difficulty for the market and investments to manage the managers' performance. To test this variable, the researcher divided the sample firms into firms having high information asymmetry and others with low information asymmetry as revealed in Table (1).

It is worth noting that the biggest gap between the management and the users of accounting information in the firm can be found in banking sector. The average percentage of information asymmetry in this sector is $7.35 \%$ (as exposed in Table 2). The researcher supposes that the explanation for this matter is attributed to the high uncertainty in the disclosure, which is one of the critical success elements of banking activity.

3. Financial leverage: This variable is measured by total debt to total assets. To test the impact of this variable, the researcher utilizes the same way in classifying the firm sample of the current study following the management ownership and information asymmetry. It is noted in Table (2) that the highest financial leverage was for the banking sector. For the dependent variable in the current study, which is agency cost, it utilizes measures used by Ang et al (2002). He used two measurements: the asset utilization ratio and expense ratio. In this study, the researcher will depend on using the second one because it is related to the excessive expenses that are more common type of agency cost in Iraqi firms.

For agency cost of ownership for the selected sample, it has been identified on the basis of the difference between the average of operating expenses ratio for a sample of 25 firms run by their owner with their counterparts (in the same year) in each firm of the study sample and for each year of the study period between 2010 and 2013 .

The moderator variable in the present study is firm performance: It is represented by ROI. The justification of choosing this measurement is that it shows the extent of managers' efficiency to observe the available resources of the firm to maximize the wealth of stockholders, as the firm's profitability is the finding of effective monitoring of management to the stockholders for the good firm performance resulting from the good decisions made by the top managers. In addition, this variable shows the managers' capability to create flows to ensure the survival of the firm and its continuation in the market within the competition.

To test the management behavior of Agency cost, the researcher divided the sample firms into two groups, through using mediator rate of return on investment, a segment of firms described the firms that have more return on investment than the mediator described as high firm performing firms; the number of views of this segment is 62. For the other segments of firms where the (ROI) is less than the mediator described as a low firm performing, the number of observations is 46 . It is worth mentioning that the highest (ROI) was for the banking sector with an average $16.4 \%$, whilst the industrial sector was less than the mediator (ROI) by $5.7 \%$ because of the strong competition.

Table 1: Classification of study sample according to statistical testrequirements

\begin{tabular}{|c|c|c|c|c|c|c|c|c|c|}
\hline \multirow{2}{*}{$\begin{array}{l}\text { Type of } \\
\text { sector }\end{array}$} & \multirow{2}{*}{$\begin{array}{c}\text { Sample } \\
\text { observations }\end{array}$} & \multicolumn{2}{|c|}{$\begin{array}{l}\text { Description based } \\
\text { on performance }\end{array}$} & \multicolumn{2}{|c|}{$\begin{array}{r}\text { Description based on } \\
\text { management ownership }\end{array}$} & \multicolumn{2}{|c|}{$\begin{array}{l}\text { Description based on } \\
\text { information asymmetry }\end{array}$} & \multicolumn{2}{|c|}{$\begin{array}{l}\text { Description based on } \\
\text { financial leverage }\end{array}$} \\
\hline & & High & Low & High rate & Low rate & High & Low & High & Low \\
\hline Banking & 60 & 42 & 18 & 36 & 24 & 38 & 22 & 47 & 13 \\
\hline Industrial & 28 & 12 & 16 & 17 & 11 & 17 & 11 & 9 & 19 \\
\hline Service & 20 & 8 & 12 & 12 & 8 & 11 & 9 & 7 & 13 \\
\hline Total & 108 & 62 & 46 & 65 & 43 & 66 & 42 & 63 & 45 \\
\hline
\end{tabular}

\section{Research Sample and Model}

Sample of the present study is 63 firms registered in Iraq Stock Exchange in the period between 2010 and 2013. The present study choses a sample based on the large proportion of the firm's operating expenses compared to the average of population as a whole. It has reached 27 firms distributed to 3 sectors namely: Industrial $25.9 \%$, Banking- 55.6\%, and the rest is Service sector. In order to examine the sample of the study, the researcher predicted the following hypothesis:

\section{Volume 5 Issue 1, January 2016}




\section{International Journal of Science and Research (IJSR) \\ ISSN (Online): 2319-7064}

Index Copernicus Value (2013): 6.14 | Impact Factor (2014): 5.611

H: All firms in the sample of the current study are characterized by the high rate of their operatingexpenses. to the percentage of management ownership, financial leverage, and information asymmetry.

The test of M.W leads to accept the hypothesis at the level of

$2.7 \%$, and Table (2) shows the sample distribution according

Table 2: Description of the study sample on the basis of average value of variables

\begin{tabular}{|c|c|c|c|c|c|c|c|c|}
\hline Details & \multicolumn{3}{|c|}{ Size of the Sample } & \multicolumn{5}{|c|}{ Description of theSample based on: } \\
\hline $\begin{array}{c}\text { Type of } \\
\text { sector }\end{array}$ & $\begin{array}{c}\text { No. } \\
\text { of firms }\end{array}$ & $\begin{array}{c}\text { Sample } \\
\text { observations }\end{array}$ & $\begin{array}{c}\text { Mediator } \\
\text { of management } \\
\text { rate }\end{array}$ & $\begin{array}{c}\text { Mediator of } \\
\text { agency cost }\end{array}$ & $\begin{array}{c}\text { Mediator } \\
\text { of } \\
\text { performance }\end{array}$ & $\begin{array}{c}\text { Mediator } \\
\text { of management } \\
\text { ownership rate }\end{array}$ & $\begin{array}{c}\text { Mediator } \\
\text { of information } \\
\text { Asymmetry }\end{array}$ & $\begin{array}{c}\text { Mediator } \\
\text { of financil } \\
\text { leverage }\end{array}$ \\
\hline Banking & 15 & 60 & 55.6 & $13.8 \%$ & $12.6 \%$ & 13.94 & 7.35 & $82.18 \%$ \\
\hline Industrial & 7 & 28 & 25.9 & $11.7 \%$ & $9.4 \%$ & 9.31 & 4.14 & $29.04 \%$ \\
\hline Service & 5 & 20 & 18.5 & $5.79 \%$ & $11.3 \%$ & 5.12 & 4.08 & $20.78 \%$ \\
\hline
\end{tabular}

The model of the study is based on study variables and its hypotheses, as follows:

$$
\begin{aligned}
& A C=\alpha_{0}+\alpha_{1} B O D+\alpha_{2} I N E D+\alpha_{3} C E O d u a l i t y+\alpha_{4} M 1+\alpha_{4} M 2+\alpha_{4} M 3+\varepsilon \\
& A C_{i t}=\alpha_{0}+\alpha_{1} F L G_{i t}+\alpha_{2} I A S_{i t}+\alpha_{3} M O_{i t}+\alpha_{4} M 1_{i t}+\alpha_{4} M 2_{i t}+\alpha_{4} M 3_{i t}+\varepsilon_{i t}
\end{aligned}
$$

Where $A C$ denotes agency cost of Iraqi firms, $F L G$ is financial leverage, IAS stands for information asymmetry, $M O$ is management ownership and M1, M2 and M3 are interaction of FLG, IAS and MO with performance, respectively.

Firstly, it must be tested whether or not the distribution of the population that the sample is chosen naturally before choosing the suitable statistical method to test all the hypotheses of the study. To do so, the researcher used Lillefor's test for normality that based on standard deviation and mean of a single total assets of the sample of the study, as shown below:

H0: The data of the study sample computed from the original community is characterized by normal distribution at $5 \%$ level of significance.

The following form shows how the test was conducted: $\mathrm{T}=\sup (\mathrm{x})\left|\mathrm{F}^{*}(\mathrm{x})-\mathrm{S}(\mathrm{x})\right|$

Where:

Sup = Largest period between $\mathrm{F}^{*}(\mathrm{x}), \mathrm{S}(\mathrm{x})$

$\mathrm{F}^{*}(\mathrm{x})=$ Normal distribution function

$\mathrm{S}(\mathrm{x})=$ Distribution function test of the sample

After computing for $\mathrm{S}(\mathrm{x})$, it was revealed that the biggest difference between each of the $\mathrm{F} *(\mathrm{~s})$ and $\mathrm{S}(\mathrm{x})$ was 0.178 , whereas the indexed value W.95 was less than the computed $\mathrm{T}$ value, the null hypothesis was rejected. Therefore, it must use nonparametric statistical tests; and then for this aim, the researcher will use Kendall correlation to measure the relationship between two variables and KolmogorovSmirnov test the divergences between the two variables.

\section{Results}

Hypotheses of the current study were tested. For H1: Agency cost in a year is equal to less than the agency cost for the firm in previous year.
It is revealed in Table (3) that the rate of annual growth the agency cost increased over the years of the study, where the figure of the standard cost in 2013 was with average of 199.59 compared to what was in 2010 , this is proved by the results of K-S test which came to reject the hypothesis for all years of the current study. This reveals that the top management in the study sample is marching towards utilizing these costs to create empires in their firms that makes it immune against punishment of the shareholders. This is revealed by the statistical procedures done by the current study about restricting the managers survival duration in their position, revealing that $74.1 \%$ of directors are still in the management positions for five years. The present study attributes such result to two reasons: first lies in the lack of managers' oversight and control due to many fragmentations in the structure of ownership with the high ratio of minority stockholders who lack the how ofcontroling the managers. Second reason is related to the managers in the study sample in terms of the ratio of their ownership of shares in the capital of the firm, the average of management ownership in the study sample around $10.43 \%$, which is low compared to neighboring countries like Jordan which reaches about 30\% (Al-shaip and Abu Tapanjeh, 2005).

Table 3: Results of first hypothesistest

\begin{tabular}{|c|c|c|c|c|}
\hline $\begin{array}{c}\text { Years } \\
\text { details }\end{array}$ & $\mathbf{2 0 1 0}$ & $\mathbf{2 0 1 1}$ & $\mathbf{2 0 1 2}$ & $\mathbf{2 0 1 3}$ \\
\hline Mediator of agency cost & $7.3 \%$ & $8.8 \%$ & $11.05 \%$ & $14.57 \%$ \\
\hline Annual growth rate & & $34.25 \%$ & $25.6 \%$ & $31.86 \%$ \\
\hline Cost index & & $134.25 \%$ & $151.37 \%$ & $199.59 \%$ \\
\hline K-S test results & \multicolumn{5}{|l}{} \\
\hline calculated value & & 13.6 & 14.03 & 12.83 \\
\hline Level of significance & & 3.66 & 4.85 & 3.91 \\
\hline Decision rule & & Reject H1 & Reject H2 & Reject H3 \\
\hline
\end{tabular}

For the second Hypothesis, H2: Agency cost is not affected by the determinants: management ownership, financial leverage, and information asymmetry, the researcher in the current study noted a weakness in the relations between agency cost and managerial ownership rate. This rate did not exceed $8.35 \%$, however when the management

\section{Volume 5 Issue 1, January 2016 www.ijsr.net}




\section{International Journal of Science and Research (IJSR) \\ ISSN (Online): 2319-7064}

Index Copernicus Value (2013): 6.14 | Impact Factor (2014): 5.611

ownership exceeds such a ratio, the relationship with agency cost becomes significant and positive.

The researcher believes that this relation is acceptable because of the large percentage of minority stockholders" contribution in the capital structure of the sample of the study that is about $50 \%$, and this percentage will make managers invest in a portion of the net cash flows of the firm by the exploitation of agency cost.
Due to rising this agency cost, this will lead to the necessity of reducing net cash flows of the firm and moreover the share of such flows. KS test shows the significant differences in the relationship between the agency cost size of the sample with a high percentage of management ownership (see Table 4).

Table 4: Results of testing management ownership rate effect

\begin{tabular}{|c|c|c|c|c|c|}
\hline \multicolumn{2}{|l|}{ Details } & & 2011 & 2012 & 2013 \\
\hline \multicolumn{2}{|l|}{ Lowest rate of management ownership } & & 7.34 & 6.12 & 5.9 \\
\hline \multicolumn{2}{|l|}{ highest rate of management ownership } & 94 & 14.92 & 14.56 & 11.86 \\
\hline \multicolumn{6}{|c|}{$\begin{array}{c}\text { Kendal sample test: } \\
\text { To the level } 8.35 \% \text { of management ownership rate } \\
\text { Sample size } 47 \text { observations } \\
\text { calculated value }(0.328) \\
\text { Level of significance } 3.35 \% \\
\text { after level of } 8.35 \% \text { of management ownership rate: } \\
\text { Sample size is } 61 \text { observations } \\
\text { calculated value } 0.286\end{array}$} \\
\hline \multicolumn{6}{|c|}{ K-s test } \\
\hline \multirow[t]{2}{*}{ Details } & $\mathrm{Ob}$ & ons of Sample & \multirow{2}{*}{$\begin{array}{c}\text { Calculated } \\
\text { value }\end{array}$} & \multirow{2}{*}{$\begin{array}{c}\text { significance } \\
\text { level }\end{array}$} & \multirow[t]{2}{*}{ Decision } \\
\hline & N1 & N2 & & & \\
\hline All study years & 65 & 43 & 359.6 & $2.13 \%$ & Rejected \\
\hline 2010 & 17 & 10 & 83.45 & $4.18 \%$ & Rejected \\
\hline 2011 & 14 & 13 & 79.16 & $2.49 \%$ & Rejected \\
\hline 2012 & 16 & 11 & 81.22 & $3.17 \%$ & Rejected \\
\hline 2013 & 12 & 15 & 92.4 & $3.65 \%$ & Rejected \\
\hline
\end{tabular}

Regarding informationasymmetry, the results about correlation got from Kendal measures are shown. It shows there is a significant correlation between the size of agency cost and information asymmetry in spite of the high rate of market value in most of the firms of the current study during the study years, that means based on such a measurement, the difficulty of controlling by stockholders and consumers in the Iraq financial market to the firm performance of managers is allowing the latter a chance to spend further agency cost.

\section{Effect of information asymmetry tested}

The results of Kendal measures of correlation are listed; there is an absent and significant statistically correlation between information asymmetry and size of agency theory despite the high percentage of market value of the stock to its book value in most of the companies' sample of the study during the years of the study, which means based on this measurement, the difficulty of monitoring by shareholders and customers in the financial market to the performance of managers is allowing the latter an opportunity to spend more of agency cost. However, before confirming this finding, it is important to test the relation between the share of the market value and book value to prove the sound expression of this percentage about information asymmetry because the market of Stock Exchange in Iraq is weak because of the poor reaction to the disclosure of accounting information in the financial statements of firms, as the stock value in the market is not determined with firm data; however in accordance with supply mechanisms and speculation or demand, this leads to the viewpoint that the gap between the two values is large.
Thus, the study measures Kendal correlation for two values. It shows that there is an absent correlation between the market value and its book value. The study concludes that such a ratio is not active to convey the information asymmetry, and cannot be described to be as one of the determinants of management behavior in the perspective of agency cost. This conclusion proves the results of K-S test that did not explain significant differences between agency cost in the part of the sample with a high asymmetry and its counterpart in the other part of the study sample with a low information asymmetry.

The results about financial leverage are illustrated in Kendal measures that demonstrate the insignificant relationship between financial leverage and agency cost. Moreover, the result of statistical test again came according to what was perceived, where testresults of Kendal measures show lack of a statistically significant relationship between the ratio of debt and the size of the agency cost of ownership. As well, K-S test doesn't reveal significant changes between the agency cost in the sample that has high financial leverage ratio and its counterpart in the other part that has low financial leverage ratio. This reveals that this variable is not as a determinant to the management behavior of spending agency cost in the case of Iraq. This conclusion may be pretty correct in spite of incompatibility with the results of several previous studies in the literature due to the lack of adaptation of the Iraqi firms on loans to finance their needs

\section{Volume 5 Issue 1, January 2016 www.ijsr.net}




\section{International Journal of Science and Research (IJSR) \\ ISSN (Online): 2319-7064 \\ Index Copernicus Value (2013): 6.14 | Impact Factor (2014): 5.611}

The results in the current study reveal H3: There is no effect of firm performance on the relation between agency cost and all determinants of managerial behavior. Therefore, there is no effect of the three determinants in determining this relationship. The effect of performance management ownership demonstrated a strong relationship

The influence of performance on management ownership ratio shows there is a strong inverse correlation between management ownership and agency cost in the sample of the study whose performance is low, where in this regard, the agency cost decreases when the management ownership increases, and vise versa.The reason of this case is that the managers who have a large management ownership peruse to have low agency cost for the purpose of improving the profit of the firm because this improvement has a positive impact on the share price in the financial market. The interpretation about managers behavior, when they have low management ownership in the firm, to increase agency cost is the desire that they have to maximize their own benefit, while in the high firm performance sample, the association is strong and there is a positive association between management ownership and agency cost. On the other hand, the impact of performance on information asymmetry shows that market value has high firm performance that less than their counterparts in low-performing firms, while the comparative analysis of the association between agency cost within the two segments did not reveal effect of the firm performance on this relationship, whereas Kendal test shows that the hypothesis is accepted. Therefore, such result confirms the illustration brought by the current study for the absence of relationship between agency cost and information asymmetry. Moreover, the present study sees that there is no significant effect of performance on the relation between financial leverage and agency cost; whereas the results revealed that there is no significant relation between the two variables in both segments of the firms. Therefore, the current study does not support the assumption brought by Jensen and Meckling (1976) stating that financing company by debts compared to management ownership must increase management ownership that would align the interests between the stockholders and the managers, and then limit the agency problems.

\section{Conclusion}

The present study aimed at investigating the determinants of agency costs in one of emerging markets, namely Iraq,through using data from banking, industrial, and service sectors. The study covered all the non-financial and financial Iraqi firms for the period from 2010 to 2013. The study shows that there is conflict of interests with increasing in agency problems in Iraqi firms that led to high agency cost in these firms. Furthermore, it revealed that management ownership is considered as a vital economic motive that affect agency problems in the case of Iraqi firms. In addition, there is a difficulty in computing information asymmetry in Iraqi firms through the market value of shares to the book value. Iraqi financial market is weak facing difficulty to respond to the firms' requirements. Therefore, it is impossible for stockholders and other market participants to oversee and control managers' performance. Besides, the vital role is played by financial leverage to force the management to alleviate agency cost. Therefore, the management in Iraqi firms are to provide more disclosure and transparency regarding the performance of the firms and make sure to encourage financial market participants to rely on financial reports rather than rely on brokerage in order to eventually reduce information asymmetry. Finally, it is recommended to the future studies to test the kind of industry and age of firms as control variablesto be tested and added to the variables used in order to avoid the potential effect that might exist in such variables.

\section{References}

[1] Abor, J. (2007). Debt policy and performance of SMEs: Evidence from Ghanaian and South African firms. The Journal of Risk Finance, 8(4), 364-379.

[2] Alabdullah, T. T. Y., Alfadhl, M. M. A., Yahya, S., \& Rabi, A. M. A. (2014). The Role of Forensic Accounting in Reducing Financial Corruption: A Study in Iraq. International Journal of Business and Management, 9(1), p26.

[3] Alabdullah, T. T. Y., Yahya, S., \& Ramayah, T. (2014). Corporate Governance Mechanisms and Jordanian Companies' Financial Performance. Asian Social Science, 10(22), p247.

[4] Alabdullah, T. T. Y., Yahya, S., \& Thurasamy, R. (2014). Corporate Governance Development: New or Old Concept. European Journal of Business and Management, 6(7),312-315.

[5] Al-Najjar, B. (2010). Corporate governance and institutional ownership: evidence from Jordan. Corporate Governance: Theinternational journal of business in society, 10(2), 176-190.

[6] Al-Shiab, M., \& Abu-Tapanjeh, A. (2005). Ownership structure and firm performance: The case of Jordan. Journal of Business Administration, 1(2), $1-27$.

[7] Ang, J.S., Cole, R.A., \& Lin, J.W. (2002). Agency costs andownership structure.the Journal of Finance, 55(1), 81-106.

[8] Berle, A. A., \& Means, G. C. (1932). The Modern Corporation and Private Property(MacMillan, New York, NY).

[9] Chen, C.R., Guo, W., \& Mande, V. (2006). Corporate value, managerial stockholdings and investments of Japanese firms. Journal of International Financial Management \& Accounting, 17(1), 29-51.

[10] Chen, P.C., \& Fang, S.C. (2011). Can agency theory disclose organizational commitment? Exploring employees and agency workers. Paper presented at the Technology Management Conference (ITMC), InternationalConference on (100-102). IEEE.

[11] Chuang, L., Xiuhong, L., \& Lei, Z. (2010). Earnings Quality and the Agency Costs of Controlling Shareholder. Paper presented at the E-Business and E-Government (ICEE), International Conference on (pp. 5132-5135). IEEE.

[12] Eisenhardt, K.M. (1989). Agency theory: An assessment and review. Academy of management review, 57-74.

[13] Fama, E.F., \& Jensen, M.C. (1983). Separation of ownership and control. JL \& Econ.,26, 301.

\section{Volume 5 Issue 1, January 2016 www.ijsr.net}




\section{International Journal of Science and Research (IJSR) \\ ISSN (Online): 2319-7064 \\ Index Copernicus Value (2013): 6.14 | Impact Factor (2014): 5.611}

[14] Harris, O., \& Glegg, C. (2009). Governance quality and privately negotiated stock repurchases: Evidence of agency conflict. Journal of Banking \& Finance, 33(2), 317-325

[15] Harris, M., \& Raviv, A. (2010). Control of corporate decisions: shareholders vs. management. Review of Financial Studies, 23(11), 4115-4147 .

[16] Harvey, C.R., Lins, K.V., \& Roper, A.H. (2004). The effect of capital structure when expected agency costs are extreme. Journal of Financial Economics, 74(1), 3-30.

[17] Hayek, F.A. (1945). The use of knowledge in society.The American Economic Review, 519-530.

[18] Hill, C.W.L., \& Jones, T.M. (1992). Stakeholder-agency theory. Journal of management studies, 29(2), 131154 .

[19] Jensen, Michael C. "Agency cost of free cash flow, corporate finance, and takeovers." Corporate Finance, and Takeovers. American Economic Review 76.2 (1986).

[20] Jensen, M.C., \& Meckling, W.H. (1976). Theory of the firm: Managerial behavior, agency costs and ownership structure. Journal of financial economics, 3(4), 305360.

[21] Jensen, M., \& Meckling, W. (1995). Specific and general knowledge and organizational structure.Harvard University Press.

[22] Jensen, M.C. (2008). Agency costs of overvalued equity. Financial Management,34(1), 5-19.

[23] Kim K.A. \& Nofsinger J.R., (2007), Corporate Governance - Second Edition, Pearson Education, Inc., Upper Saddle River, New Jersey.

[24] Lopez de Silanes, F., Vishny, R., \& Shleifer, A. (2000). Agency problems and dividend policies

[25] around the world. Journal of finance, 60(1), 1-33.

[26] Margaritis, D., \& Psillaki, M. (2010). Capital structure, equity ownership and firm performance. Journal of banking \& finance, 34(3), 621-632 .

[27] Moldoveanu, M., \& Martin, R. (2001). Agency theory and the design of efficient governance mechanisms. document de travail, Joseph L. Rotman School of Management, Université de Toronto, 2.

[28] Pinteris, G. (2002). Ownership structure, Board characteristics and performance of Argentine Banks. Urbana, 51, 61801.

[29] Shi, H., \& Song, X. (2011). Overview and analysis of capital structure and output markets competition using agency costs theory. Paper presented at the Artificial Intelligence, Management Science and Electronic Commerce (AIMSEC), 2nd International Conference on (pp. 3160-3163),IEEE.

[30] So, J. (2005) “Agency costs and ownership structure: evidence from the small business finance survey data base" Office of Advocacy, U.S. Small Business Administration No. 268.

[31] Tong, S. and Ning, Y. (2004), “Does capital structure affect institutional investor choices?", The Journalof Investing, Vol. 13 No. 4, pp. 53-66

[32] Wang, G.Y. (2010). The Impacts of Free Cash Flows and Agency Costs on Firm Performance. Journal of Service Science and Management, 3(4), 408-418.
[33] Watts, R.L., \& Zimmerman, J.L. (1990). Positive accounting theory: a ten year perspective. Accounting review, 131-156.

[34] Wu, J., Zhu, X., \& Huang, G. (2011). CFO complex characteristic, agency costs and corporate value: Based on financial engineering cube concept. Paper presented at the Business Management and Electronic Information (BMEI), 2011 International Conference on( pp. 840-843).IEEE.

[35] XIE, J., JIANG, L., \& TANG, Z. (2008). Monitoring, Incentives and Equity Agency Cost: An Empirical Study Based on Business Groups of China. Journal of uangdong University of Business Studies, 4, 010.

[36] Zhang Zhao-guo; He Wei-feng; Zhu Sha-sha; "Capital Structure andAgency Costs" Management Science and Engineering, 2007.

[37] ZHOU, D., \& YANG, X. (2010). Ownership Structure, Managerial Power and.Diversified Management_B Based on Empirical Study of Listed Companies in China. Journal of Changchun University of Science and Technology (Social Sciences Edition), 5, 021. 